IBIMA Publishing

Journal of South African Business Research

http://ibimapublishing.com/articles/JSABR/2021/146557/

Vol. 2021 (2021), Article ID 146557, 11 pages, ISSN: 2169-0367

DOI: $10.5171 / 2021.146557$

Research Article

\title{
Comparing Residential Property Values in Border Towns of Lagos Megacity, Nigeria
}

\author{
Olayinka OLOKE ${ }^{1}$, Deborah JESUSEGUN ${ }^{2}$, Oluwole ALAGBE ${ }^{3}$ and \\ Ayodeji AKINDELE ${ }^{4}$
}

\author{
${ }^{1,2}$ Department of Estate Management, College of Science and Technology, Covenant University, \\ Canaanland, Ota, Ogun State, Nigeria \\ ${ }^{3}$ Department of Architecture, College of Science and Technology, Covenant University, Canaanland, \\ Ota, Ogun State Nigeria \\ ${ }^{4}$ Department of Building and Real Estate, The Hong Kong Polytechnic University, \\ Hong Kong.
}

Correspondence should be addressed to: Olayinka OLOKE; yinka.oloke@covenantuniversity.edu.ng

Received date: 15 October 2020; Accepted date: 26 January 2021; Published date: 28 May 2021

Academic Editor: Adedamola Olufunke Oluwunmi

Copyright (C) 2021. Olayinka OLOKE, Deborah JESUSEGUN, Oluwole ALAGBE and Ayodeji AKINDELE. Distributed under Creative Commons Attribution 4.0 International CC-BY 4.0

\begin{abstract}
In this study, the rental values of residential properties in two adjacent communities within the emerging Lagos megacity were examined to find out if certain correlational attributes exist. The communities selected are located in different geopolitical zones (i.e. Lagos and Ogun States), although the Lagos megacity influence has crawled and absorbed parts of Ogun state, such that the physical boundary has virtually vanished. Residents in the two communities as well as estate surveyors and valuers were the respondent groups involved in the study. A total of 236 questionnaires were administered. Descriptive and inferential tools of percentage means and independent sample T-test statistics were employed for the analysis, while the Pearson coefficient of correlation was used to establish the relationship between rental values in the two communities. It was found, among others, that the level of infrastructure development, enforcement of physical planning regulations, administrative jurisdiction, population density and distance to the central business district are the factors responsible for the significant differences in the magnitude of rental values between the communities. The study, therefore, suggested the investment in the physical and socioeconomic infrastructure in Ado-Odo/Ota local government area of the megacity as well as the creation of a joint development policy and programme by governments of Lagos and Ogun states so as to overcome the administrative jurisdiction barrier militating against the actualization of the megacity project.
\end{abstract}

Keywords: Adjacent, Megacity, Residential, Value

Cite this Article as: Olayinka OLOKE, Deborah JESUSEGUN, Oluwole ALAGBE and Ayodeji AKINDELE (2021)," Comparing Residential Property Values in Border Towns of Lagos Megacity, Nigeria ", Journal of Eastern Europe Research in Business and Economics Vol. 2021 (2021), Article ID 146557,

DOI: $10.5171 / 2021.146557$ 


\section{Introduction}

Physical expansion of urban settlements is a global phenomenon which, in recent times has gained momentum in regions regarded as less developed (Abiodun, Olaleye, Dokia and Odunaiya, 2011). The pattern of growth and development of urban areas is defined by several factors. While factors like presence of modern infrastructures such as pipe borne water, electricity, good road network etc.; access to social services and sporting facilities; employment opportunities; concentration of industrial and commercial activities, location of administrative and other government establishments etc. continue to attract population into urban areas, other factors like the increase in crimes rate, environmental pollution, rising cost of living, rising cost of housing and land procurement, traffic challenge, deteriorating infrastructure, retirement and old age related reasons and several other factors over the years have pushed human population out of urban areas to peri-urban and rural fringes in droves. Recently, several peri-urban areas are experiencing population growth on a scale that is unprecedented. For instance, Adelekan, Olajide-Taiwo, Ayorinde, Ajayi, and Babajide (2014) stated that while the average population growth rate per year in Ibadan metropolis was 0.5 percent between 1991 and 2006, the average growth rate for the peri-urban areas was 4.8 percent over the same period. Urbanization is the lead cause of periurbanization and this according to Adelekan (2016), is a process whereby extensive areas earlier characterized by rural features get absorbed into the city or transformed into peri-urban areas. Periurbanization gradually absorbs existing physical developments and paves way for modern structures, social as well as economic infrastructure developments. People move from overcrowded city centers to the less populated sub-urban areas. As the population of these areas increases, demands for land for different uses such as housing, commercial, education, administration and financial services as well as other economic purposes also increase. In most developing nations where physical planning regulations are weak and suffer poor implementation, sub-urban growth and developments are often unplanned, uncontrolled and disorganized, exposing the residents to diverse environmental risks and hazards.

Bloch, Fox, Monroy and Ojo, (2015) observed that the growth of Nigeria's urban population has been accompanied by the expansion of existing built-up areas and the emergence of new and identifiably urban settlements. For instance, Lagos megacity according to Mehrotra et. al., (2009), is one of the fastest growing urban centres. Aside the official estimate of about 9 million according to NPC (2006), the UNHabitat estimated the city's population to be about 15 million in 2006 with 600,000 additional migrants added each year. This has been projected to about 20 million in 2015. Lagos state, according to Salau, Lawanson and Odumbaku (2013) has continued to grow in terms of population and space, spilling excess population into the neighbouring Ogun state. The Lagos megacity project covers the whole of Lagos state and four local governments in Ogun State which are at the border of Lagos State. These include: Ado-Odo/Ota, Ifo, Obafemi-Owode and Sagamu (Bello and Olatubara, 2014). The Ogun State Government report (2015) revealed that Lagos' side of the megacity is made up of $74 \%$ of the built-up area and has $85 \%$ of the megacity population. Ogun state's side on the other hand has $26 \%$ of the built up area and accounts for about $15 \%$ of the megacity population. The communities in adjoining local government to Lagos State that forms part of Lagos State continues to experience influx of population from the over-populated Lagos metropolis. Thus, the dual character of the Lagos megacity which comprises communities from two different geographical and administrative jurisdictions prompted the study. The study analysed and compared residential property values of border communities under the umbrella of Lagos megacity project. 


\section{Literature Review}

\section{Urban growth and development pattern}

Ogu (2005) described the postindependence urban development process in Nigeria in the form of growth by densification and growth by expansion. This, as explained, exists at the edges of existing urban areas and refers to the appearance of new parts of a city. Atu et. al., (2012) opined that this occurs when detached improvements and settlements that were not part of urban areas are absorbed at the city borders as a result of physical expansion. This aptly describes the urban development process that witnessed the fusion of scattered neighbourhoods that were hitherto located within the fringes of Lagos metropolis. Growth by densification, on the other hand, describes the emergence of independent houses in areas previously occupied by single large housing structures (Bloch, Monroy, Fox and Ojo, 2015). This pattern of growth as explained in the study, is common with urban cores or existing urban areas and has led to the appearance of various forms of development within the traditional core of Nigerian cities, notably the emergence of informal settlements. This does not only explain the process of urban transformation witnessed in major city centers such as Ibadan, Abeokuta and Lagos, but also that of Ota town in AdoOdo/Ota Local government area of the Lagos megacity. Ota was a core ancient town with distinct cultural and morphological characteristics and a largely homogenous population. The expansion cum explosion of Lagos population have, over the past decades, diluted the homogenous population of ancient AdoOdo/Ota towns and triggered the appearance of various socio-economic, administrative structures and infrastructures typical of any urban transformation process. Thus, urban expansion connotes the improvement and expansion of urban areas in terms of size in order to create space for urban growth. Urban growth results from three processes namely; natural population growth, ruralurban migration and reclassification of rural areas into urban ones. The emergence of Lagos megacity and the physical and geographical coverage, therefore, reflects the underlying process of these three forces at work. However, Bloch et al., (2015) found out that urban growth and development further depends on the prevailing political and economic situation as well as government control mechanism. Lack of good government control results in spontaneous patterns of growth around urban fringes, while proper control sets unnecessary expansion within limits. Urban growth and development increases competition among land use and resources, urban land cost and ultimately, renters and owner's housing procurement costs.

\section{Urban Infrastructure Development}

Infrastructure development is one vital socio-economic factor that makes a human settlement urban and livable. The basic infrastructure that facilitates development in any neighbourhood includes housing, good road network, drainage, electricity, decent water supply system, waste management system, primary healthcare facilities, educational facilities, effective security architecture combined with wellplanned and coordinated developments. Urban infrastructure provision is not only the responsibility of the government alone. The influx of people into the sub-urban areas of a city only culminates in demand for more housing and other socio-economic infrastructures. These demands not only need urgent government intervention in many areas but also create viable opportunities for private sector participation. Infrastructure development is found to be a vital factor that determines the value of a neighbourhood and is reflected in land and property values in the area. According to Oloke, Simon and Adesulu (2013), the level of infrastructure development in a neighbourhood is very critical to determining housing prices and attracts huge investments in a broad range of real estate products as well. Providing infrastructures throughout the country has become almost impossible for the government, and as such, it has become important for the private sector and other stakeholders to contribute to infrastructure provision. Bello, Adeniji and 
Arowosegbe (2015) identified four participants in the provision of urban infrastructures namely: the government, the formal private sector, the informal private sector, and the residents of the affected community. Alyafei, (2017) revealed that the government of Quatar considers the involvement of residents as key to the country's progressive development. Ahuja and Priyadarshini (2017) also emphasized that people affected by a development need to be duly informed in order for them to be involved in the development. It was also noted by Ahuja and Priyadarshini, (2017) that the goal of sustainable development is likely to be achieved when the affected communities are actively involved in the process so that they do not indirectly impede on the benefits of the infrastructures provided.

\section{Urban Infrastructure and Property Value}

Urban infrastructure and property value are closely connected as the level of development or the state of infrastructure determines the value of property in the vicinity. Real estate products include vacant/virgin land, and developed land ranging from housing to industrial, commercial, administrative, health and educational facilities, recreational, entertainment and hospitality developments as well as market structures located in an area. Land and landed properties are either rented or purchased to meet these different purposes and coupled with the portion of land laid out for infrastructure provision. The competing uses for land resources, in most times, results in an enhanced value of land and landed properties in an urbanizing neighbourhood. Other dimensions of value, largely grouped as statutory or nonstatutory values, though exist for properties, are generally affected by the level or state of infrastructure. Property value worldwide is a metric for assessing the level of development in any given area. The higher the value of properties, the higher the level of development in that location and vice-versa. This explains why different places, having a unique property market as location determines value to a large extent. Different studies have investigated the impact of different infrastructures on the residential property value. For instance, Qin, Yu, and Liu (2019) examined the impacts of the HOPSCA (Hotels, Offices, Parks, Shopping malls, Convention centers, and Apartments) facilities on housing prices and found that HOPSCA had both positive and negative impacts on accommodation values. It was observed that different cases of HOPSCA had different impacts on accommodation values according to the situation and mode of arrangement. Also, Gargiulo (2010) assessed the impact of city renewals, focusing on the construction of an extravagantly fast rail route and its effect on property prices. The study also concluded that the development of a fast rail system drastically increased property values in the area. In addition, the larger developed city centres were very much affected as the transport infrastructure helped revived the blighted areas. Bello, Adeniji, and Arowosegbe (2015) examined the importance of urban facilities to property values in Abeokuta's city center, Ogun state, Nigeria. It was concluded that the provision and condition of infrastructural services led to an enormous rise in price. In order to place the pace of development of communities under the Lagos megacity project on the same page with the agenda of the vision, this study was conducted to serve as a development metric, particularly for the border communities.

\section{Research Methods}

Result Analysis

Response analysis 
Table 1: Analysis of response

\begin{tabular}{|l|l|l|l|l|}
\hline Questionnaires & Joke-Ayo (Lagos) & $\begin{array}{l}\text { Akeja } \\
\text { (Ogun) }\end{array}$ & Estate Firms & Total \\
\hline No. Administered & 89 & 63 & 84 & 236 \\
\hline No. Retrieved & 73 & 54 & 65 & 187 \\
\hline Response rate (\%) & 82.0 & 85.7 & 77.4 & $79.2 \%$ \\
\hline
\end{tabular}

One hundred and fifty-two (152) questionnaires were administered to household heads within the selected border communities. A total of 122 were retrieved constituting 83.6 percent response level. This was sufficient for subsequent analysis. The pattern of questionnaire administration and retrieval rate is as shown in Table 1.

Types of residential property in selected neighbourhoods

Table 2: Types of residential property in the communities

\begin{tabular}{|c|l|c|c|c|c|}
\hline \multirow{2}{*}{$\begin{array}{l}\text { Property } \\
\text { Type }\end{array}$} & Property & \multicolumn{2}{|c|}{$\begin{array}{c}\text { Joke-Ayo (Lagos) } \\
\text { No. Percentage }\end{array}$} & \multicolumn{2}{c|}{ Akeja (Ogun) } \\
Percentage \\
\hline Type 1 & Tenement building & 3 & $4.1 \%$ & 12 & $22.2 \%$ \\
\hline Type 2 & Self-contained & 5 & $6.8 \%$ & 3 & $5.6 \%$ \\
\hline Type 3* & Blk of 2 bdrm flats & 11 & $15.1 \%$ & 9 & $16.7 \%$ \\
\hline Type 4** & Blk of 3 bdrm flats & 17 & $23.3 \%$ & 11 & $20.4 \%$ \\
\hline Type 5 & 2 & & & & \\
\hline Type 6 6 & 3 & 3 & $4.1 \%$ & 5 & $9.3 \%$ \\
\hline bypedroom 7 & Semi-detached & 7 & $9.5 \%$ & 4 & $7.4 \%$ \\
\hline Type 8 & Fully-detached & 10 & $13.7 \%$ & 2 & $3.7 \%$ \\
\hline Total & & 73 & 100 & 54 & 100 \\
\hline
\end{tabular}

Key:

*Block of 2 Bedroom Flats

**Block of 3 Bedroom Flats

Table 2 contains the different types of accommodation of respondents in the study area. The Table revealed that tenement buildings are common in Akeju community having $22.2 \%$ of the number of houses captured compared to blocks of 3 bedroom flat and 3 bedroom bungalow that have $16.7 \%$ and $20.4 \%$ respectively within the same community. However, blocks of 3bedroom flats and 2-bedroom bungalow have the highest occurrence with $23.3 \%$ each in the Joke-Ayo community of Lagos State. The survey further revealed fewer types of modern design accommodation in Akeju compared to Joke-Ayo neighbourhood.

Table 3 presents the average rental value of accommodation types in the two neighbourhoods over a period of 6 years. This was obtained from the responses of professional property managers surveyed. 
The figures were estimates of a range of values supplied by the valuers for each property type between 2014 and 2020. It was observed that the average rental values increase in both communities during some periods but remain constant at some other periods. For instance, similar average rent was observed in 2019 and 2020. However, neither the rate of growth nor the relationship between the values was immediately clear from the Table.

Table 3: Average rental value of residential properties in Joke-Ayo and Akeja communities

\begin{tabular}{|l|l|l|l|l|l|l|l|l|}
\hline Types & \multicolumn{2}{|c|}{$\mathbf{2 0 1 4}$} & \multicolumn{2}{c|}{2015} & \multicolumn{2}{c|}{2016} & \multicolumn{2}{c|}{2017} \\
\hline & $\begin{array}{l}\text { Ave- } \\
\text { Ayo }\end{array}$ & Akeja & $\begin{array}{l}\text { Joke- } \\
\text { Ayo }\end{array}$ & Akeja & $\begin{array}{l}\text { Joke- } \\
\text { Ayo }\end{array}$ & Akeja & $\begin{array}{l}\text { Joke- } \\
\text { Ayo }\end{array}$ & Akeja \\
\hline Type 1 & 30,000 & 12,000 & 45,000 & 15,000 & 50,000 & 18,000 & 60,000 & 24,000 \\
\hline Type 2 & 90,000 & 22,500 & 120,000 & 25,000 & 120,000 & 35,000 & 150,000 & 50,000 \\
\hline Type 3 & 150,000 & 60,000 & 160,000 & 90,000 & 180,000 & 120,000 & 200,000 & 130,000 \\
\hline Type 4 & 180,000 & 90,000 & 200,000 & 100,000 & 240,000 & 120,000 & 250,000 & 150,000 \\
\hline Type 5 & 220,000 & 100,000 & 250,000 & 120,000 & 280,000 & 130,000 & 280,000 & 150,000 \\
\hline Type 6 & 250,000 & 110,000 & 280,000 & 140,000 & 320,000 & 170,000 & 350,000 & 200,000 \\
\hline Type 7 & 260,000 & 120,000 & 280,000 & 150,000 & 350,000 & 180,000 & 360,000 & 240,000 \\
\hline
\end{tabular}

\begin{tabular}{|c|c|c|c|c|c|c|}
\hline \multirow[t]{2}{*}{ Types } & \multicolumn{2}{|c|}{2018} & \multicolumn{2}{|c|}{2019} & \multicolumn{2}{|c|}{2020} \\
\hline & Joke-Ayo & Akeja & Joke-Ayo & Akeja & Joke-Ayo & Akeja \\
\hline Type 1 & 75,000 & 30,000 & 90,000 & 50,000 & 90,000 & 50,000 \\
\hline Type 2 & 150,000 & 75,000 & 180,000 & 90,000 & 180,000 & 90,000 \\
\hline Type 3 & 240,000 & 150,000 & 280,000 & 180,000 & 280,000 & 180,000 \\
\hline Type 4 & 280,000 & 160,000 & 300,000 & 200,000 & 300,000 & 200,000 \\
\hline
\end{tabular}

Olayinka OLOKE, Deborah JESUSEGUN, Oluwole ALAGBE and Ayodeji AKINDELE, Journal of South African Business Research, DOI: 10.5171/2021.146557 


\begin{tabular}{|l|l|l|l|l|l|l|}
\hline Type 5 & 320,000 & 180,000 & 350,000 & 220,000 & 350,000 & 220,000 \\
\hline Type 6 & 350,000 & 220,000 & 380,000 & 240,000 & 380,000 & 240,000 \\
\hline Type 7 & 400,000 & 250,000 & 420,000 & 260,000 & 420,000 & 260,000 \\
\hline Type 8 & 450,000 & 320,000 & 460,000 & 340,000 & 460,000 & 340,000 \\
\hline
\end{tabular}

Arising from Table 3, the mean rental value of all types of residential properties in the two communities were determined for each year. The result was plotted on a line graph to reveal the trend of rental values between the two communities. This is shown in Figure 1.

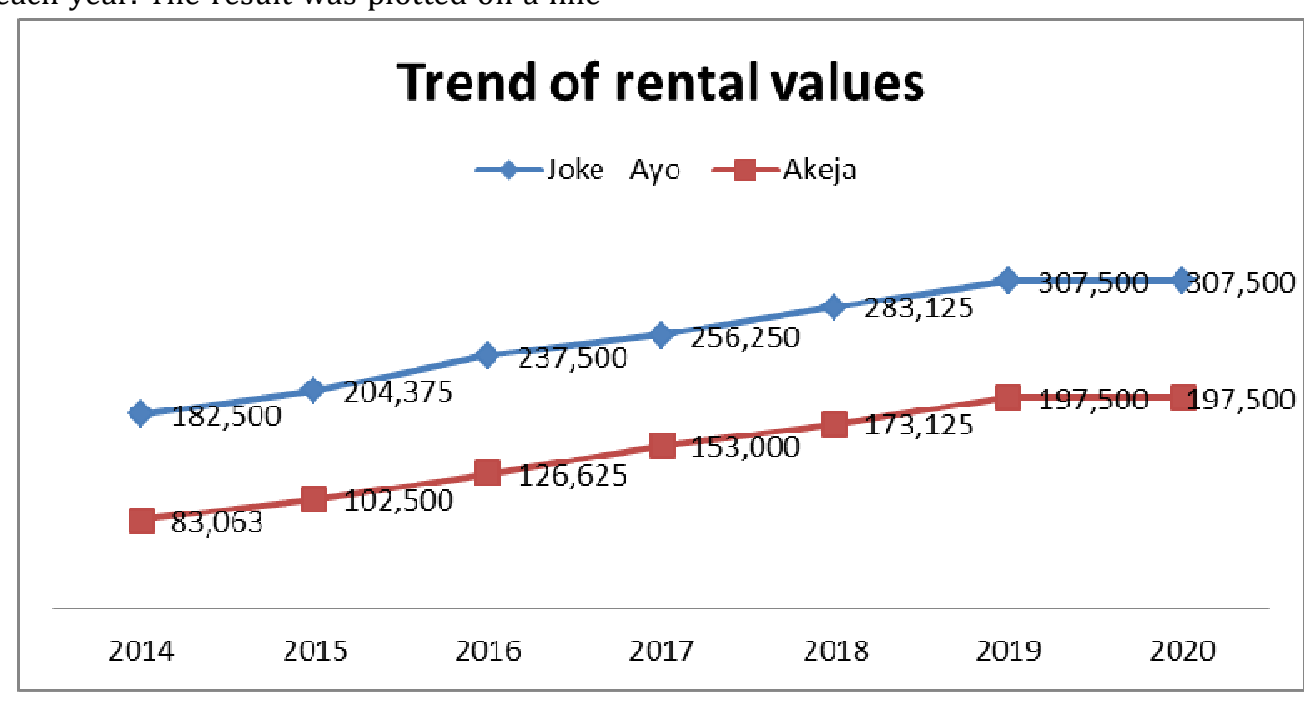

Figure 1: Trend of rental values at the selected border communities

\section{Test of hypothesis}

In order to ascertain the difference between the rental values of residential properties in the two communities, a null hypothesis was set and an independent sample test was carried out to determine the veracity of the statement of the hypothesis or otherwise. The hypothesis is stated as follows;

Null Hypothesis $\mathrm{H}_{0}$ : There is no significant difference between the statistical means of rental values of residential properties of selected border communities of Lagos and Ogun States.

Alternative Hypothesis $\mathrm{H}_{1}$ : There is a significant difference between the statistical means of rental values of residential properties of selected border communities of Lagos and Ogun States. The result of the hypothesis is as presented in Table 4. 
Table 4: Independent sample T-Test on rental values

\begin{tabular}{|c|c|c|c|c|c|c|c|c|}
\hline $\begin{array}{l}\text { Dependent } \\
\text { (Test) } \\
\text { Variable }\end{array}$ & $\begin{array}{l}\text { Independent } \\
\text { (Grouping) } \\
\text { Variables }\end{array}$ & $\mathbf{N}$ & Sig. & $\mathbf{T}$ & Df & $\begin{array}{l}\text { Sig. } \\
2- \\
\text { tailed }\end{array}$ & $\begin{array}{l}\text { Mean } \\
\text { Diff. }\end{array}$ & $\begin{array}{l}\text { Std } \\
\text { Error } \\
\text { Diff. }\end{array}$ \\
\hline & & & \multicolumn{4}{|c|}{ Equal variances assumed } & & \\
\hline \multirow[t]{2}{*}{ Rental values } & Residents & 122 & .043 & .102 & 185 & .032 & .1017 & .1964 \\
\hline & Estate valers & 65 & & & & & & \\
\hline
\end{tabular}

${ }^{*}$ Equal variances assumed ${ }^{* *} 95 \%$ confidence interval of the difference

Arising from the Table, given the Sig. value of .043 , the equality of variance is assumed. The $t$ statistic under the assumption of equal variances has a value of .102 and a degree of freedom (df) value of 185 with an associated Sig. (2-tailed) value of .032 . Since the sig. value of .032 is less than .05, the null hypothesis which states that there is no significant statistical difference between the mean rental values of residential properties in the selected border communities is rejected. By implication, the alternative hypothesis, which states that there is a significant difference between the rental values of residential property values at border communities of Lagos and Ogun States, is accepted. Furthermore, in testing the relationship between the two values of average rent per annum of residential properties in the two neighbourhood, Karl Pearson moment correlation coefficient was engaged to examine the direction and strength of the relationship. Data obtained from the professional firms were used for the analysis. A null and an alternative hypotheses were set as follows;

Null Hypothesis $\mathrm{H}_{0}$ : there is no relationship between the average rental values of residential properties in the two border communities

Alternative Hypothesis $\mathrm{H}_{1}$ : There exists a relationship between the average rental values of residential properties in the two border communities

Table 5: Test of the relationship of rental values between the two communities

\begin{tabular}{|c|c|c|c|}
\hline Correlations & & $\begin{array}{l}\text { Rental value in } \\
\text { Joke-Ayo } \\
\text { Community }\end{array}$ & $\begin{array}{l}\text { Rental value in } \\
\text { Akeja Community }\end{array}$ \\
\hline $\begin{array}{l}\text { Rental value in Joke- } \\
\text { Ayo Community }\end{array}$ & $\begin{array}{l}\text { Pearson correlation } \\
\text { Sig. (1-tailed) } \\
\mathrm{N}\end{array}$ & $\begin{array}{r}1 \\
\\
65 \\
\end{array}$ & $\begin{array}{r}.672 \\
.209 \\
65 \\
\end{array}$ \\
\hline $\begin{array}{l}\text { Rental value in Akeja } \\
\text { Community }\end{array}$ & $\begin{array}{l}\text { Pearson correlation } \\
\text { Sig. (1-tailed) } \\
\mathrm{N}\end{array}$ & $\begin{array}{r}.672 \\
.209 \\
65\end{array}$ & $\begin{array}{r}1 \\
65\end{array}$ \\
\hline
\end{tabular}

As obtained in Table 5, the Karl Pearson correlation coefficient is +0.672 and this showed that there is a relatively strong positive correlation between rental values of residential properties in the two border communities. The coefficient of correlation shows that the rental values move in the same direction albeit at significantly different magnitudes. 


\section{Factors affecting rental values in the study area}

Respondents from the estate valuation firms were asked to identify the factors affecting property values in the neighbourhoods. The responses were measured on a 5-point Likert Scale ranging from very high impact (5), high impact (4), moderate impact (3), low impact (2) to no impact (1). Results of analysis were extracted and presented.

Table 6: Factors influencing property value

\begin{tabular}{|l|l|l|l|l|}
\hline Factor & \multicolumn{2}{|c|}{ Joke-Ayo } & \multicolumn{2}{c|}{ Akeja } \\
\hline & Mean & Rank & Mean & Rank \\
\hline Population & 3.891 & 4 & 4.312 & 1 \\
\hline Infrastructure development & 4.512 & 2 & 2.918 & 5 \\
\hline Housing quality & 4.512 & 2 & 3.212 & 4 \\
\hline Geopolitical Jurisdiction & 3.891 & 6 & 2.183 & 8 \\
\hline Structural factors & 4.733 & 1 & 2.702 & 6 \\
\hline Locational factors & 4.132 & 5 & 3.691 & 2 \\
\hline Neighbourhood factors & 4.306 & 3 & 2.433 & 7 \\
\hline Economic factors & 4.141 & 4 & 2.918 & 5 \\
\hline Environmental factors & 3.633 & 7 & 3.328 & 3 \\
\hline
\end{tabular}

Table 6 presents factors affecting property values as obtained from the responses of the estate valuers, ranking the significance of each factor as perceived for each community. As shown, structural factors, level of infrastructure development, housing quality as well as locational and neighbourhood factors have a high impact on residential property values in the neighbourhood in Joke-Ayo communities. On the other hand, population density, locational factor and housing quality are factors that have a moderate impact on the rental value of residential properties in Akeja communities.

\section{Summary of Findings and Discussion}

Arising from the various analyses, it was observed that Joke-Ayo communities have more development density compared to Akeja community. This was attributed to the significant difference in the number of houses counted within the $1 \mathrm{~km}$ radius of each community whereby, there are 63 houses as against the 89 within the $1 \mathrm{~km}$ radius of each of the two communities respectively. This reveals that Joke-Ayo is a sub-urban precinct experiencing urban fringe transformation. Figure 1 showed that the mean rental value of residential properties in the two communities increased between 2014 and 2019. This implies that the border communities witnessed a similar growth pattern in the value of rental properties over the six year period. While the figure showed the pattern, Karl Pearson coefficient of correlation shows the direction and strength of the relationship between the changes in the value of rents between the two communities. The coefficient of correlation clearly showed that there is a strong positive correlation between the rental values of residential properties in the two border communities although at different magnitudes. Finally, despite the closeness of the two border communities, the significant differences in the rental value across the types of residential properties in the two communities corroborate the results in Table 5 where the study observed that different sets of factors have a very big influence on the rental values in Joke-Ayo community compared to the factors that affect similar properties in Akeja community. The finding inherently indicates that population spill from Lagos into the border communities is an important factor contributing to the trend of the rental value of residential 
properties in Akeja community of AdoOdo/Ota local government of Ogun State.

\section{Conclusion}

The study investigated the correlation between residential property rental values of selected border communities of Lagos and Ogun states. The significant disparity observed in the rental values as well as the pattern of rental growth revealed the blunt gap in the level of infrastructure development, neighbourhood density, housing quality, administrative jurisdiction and level of economic development in the two communities. Notwithstanding, the relatively strong positive correlation of rental values between the border communities is an indication of the enormous potentials of property market of the Ogun communities that border Lagos State. It is therefore recommended that Ogun state government invest in the development of socio-economic infrastructure, and renewal programmes of Ota border communities. Recommendations from this study would facilitate the achievement of targets 9 and 10 of the United Nations sustainable development goals. The goals aimed at building resilient infrastructure, promote inclusive and sustainable industrialization, foster innovation and reduce inequalities among urban dwellers.

\section{Acknowledgements}

The authors wish to acknowledge the financial support offered by Covenant University for the conduct, presentation and publication of this research.

\section{References}

- Abiodun, OE. Olaleye, JB. Dokia, AN. and Odunaiya, AK. (2011). Land use change analysis in Lagos State, Nigeria, from 1984 to 2005. FIG Working week 2011, Bridging the Gap between Cultures Marrakech, Morocco, 18-22 May 2011; TS09C - Spatial Information Processing II, 5142.

- Adelekan, I. Olajide-Taiwo, L. Ayorinde, A. Ajayi, D. and Babajide, S. (2014): Building Urban resilience: Assessing
Urban and Peri-urban Agriculture in Ibadan, Nigeria. Padgham, J. and J. Jabbour (eds.)]. United Nations Environment Programme (UNEP), Nairobi, Kenya.

- Adelekan, IO. (2016). Ibadan City Diagnostic Report. A working Paper \#4 for Urban Africa Risk Knowledge

- $\quad$ Ahuja, V. and Priyadarshini, S. (2017). Community participation in urban road infrastructure redevelopment: Indian scenario, 11(1):16-29

- Alyafei, AS. (2017). Community Participation in Sustainable Urban Development : An Applied Approach to the Impact of the New Barwa City and the Neighbouring Areas. European Journal of Social Sciences, 55(3):333344

- Atu, JE. Offiong, RA. Eni, DI. Eja, EI. and Esien, OE. (2012). The Effects of Urban Sprawl on Peripheral Agricultural Lands in Calabar, Nigeria. International Review of Social Sciences and Humanities; 2(2):68-76

- Bello, IK. Adeniji W. and Arowosegbe, OS. (2015). The effect of urban infrastructure development on property value in Abeokuta Metropolis, Nigeria. Merit Research Journal of Arts Social Sciences and Humanities 3(3):3540

- Bello, IK. and Olatubara, CO. (2014). An evaluation of the management of integrated township development in Ogun State. American Journal of Social and Management Sciences 5(2):64 - 72

- Bloch, R. Fox, S. Monroy, J. and Ojo, A. (2015). Urbanisation and urban expansion in Nigeria. Urbanisation Research Nigeria (URN) Research Report. London: ICF International. Creative Commons Attribution-NonCommercial-ShareAlike CC BY-NC-SA

- Gargiulo, C. (2010). Urban Transformation and Property Value Variation. Journal of Mobility, Land Use and Environment, 3Selected Papers (SP), 65-84

- Mehrotra, S. Natenzon, CE. Omojola, A. Folorusho, R. Gilbride, J. and Rosensweig, C. (2009) Framework for city climate risk assessment: Buenos Aires, Delhi, Lagos and New York. Fifth Urban Research Symposium 'Cities and 
climate change: responding to an urgent agenda' Marseille, France, https://www.preventionweb.net/publi cations/view/11042

- National Population Commission (2006). Baseline Projections of National Population Census 2001. Lagos State www.npc.org.ng

- Ogu, VI. (2005). Urban Infrastructure Development and Sustainability in Nigeria. Human Settlement Development, Volume III. UNESCOEOLSS

- Oloke, OC. Ijasan, KC. and Oyedele, BJ. (2013). Performance Assessment of Estate Surveying and valuation Firms in Lagos State, Nigeria. Mediterranean Journal of Social Sciences 3(13): 498498
- Oloke, OC. Simon, FR. and Adesulu, AF. (2013). An Examination of the Factors Affecting Residential Property Values in Magodo Neighbourhood, Lagos State. International Journal of Economy, Management and Social Sciences, 2(8):639-643.

- Qin, Z. Yu, Y. and Liu, D. (2019). The effect of HOPSCA on residential property values: Exploratory findings from Wuhan, China. Sustainability, MDPI, Open Access Journal, 11(2),1-18. https://doi.org/10.3390/su11020471

- Salau, T. Lawanson, T. and Odumbaku, O. (2013). Amoebic urbanization in Nigerian cities: The case of Lagos and Ota. International Journal of Architecture and Urban Development $3(4): 19-26$ 